
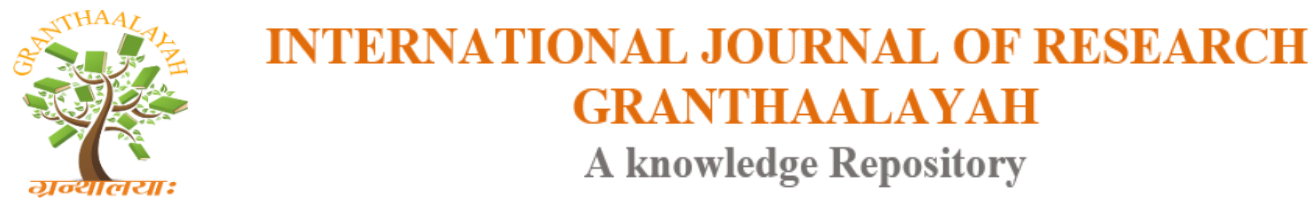

Management

\title{
A STUDY ON SELECTION OF LOCATION BY RETAIL CHAIN: BIG MART
}

\author{
Mansi Karna *1, Anusha Rai ${ }^{2}$, Bibek Karki ${ }^{3}$, Lavalesh Karna ${ }^{4}$, Miksen Rai ${ }^{5}$, Sangita \\ Adhikari ${ }^{6}$ \\ *1, 2, 3, 4, 5, 6 Department of Urban Planning, Institute of Engineering, Nepal
}

\begin{abstract}
This paper provides insight into the site-selection process that may have influenced the selection of location by retail chain store; Big Mart. The changing shopping habits and the birth of chain stores in and around Kathmandu and proceeds with the discussion on some of the models that have been used around the world. Selecting proper location for competitive advantages is a big choice for being the leader by co-creating customer and seller ecosystem. For this research, however, we have used the Analytical Hierarchy Process (AHP) and we will be delving more in detail with this method to understand the site selection method for our case area.
\end{abstract}

Keywords: Location Selection; Retail Chain; Analytical Hierarchy Process (AHP); Criteria.

Cite This Article: Mansi Karna, Anusha Rai, Bibek Karki, Lavalesh Karna, Miksen Rai, Sangita Adhikari. (2019). "A STUDY ON SELECTION OF LOCATION BY RETAIL CHAIN: BIG MART." International Journal of Research - Granthaalayah, 7(1), 383-395. https://doi.org/10.29121/granthaalayah.v7.i1.2019.1067.

\section{Introduction}

The modern day projects, such as privatized infrastructure projects, have project life that is spread over many years. Projects are becoming larger and more complex. These projects involve the large capital investment, generate unbalanced cash flows, and involve complex contractual agreements. They encounter changing economic and financial situation, face unpredictable political environmental changes. The stability of modern projects is thus, constantly subjected to certain sensitive and volatile, external and internal environments (Mishra and Mallik, 2017). Competition is increasing and companies are trying to reduce cost by reducing fixed cost i.e project construction cost for shopping center (Mishra and Chaudhary, 2018). Highly qualified personnel should be prepared conducting several professional training programs, mandatory provision of Value Management in guidelines of public entities and all the construction projects should be appointed experienced Value Manager for best outcome from the project which saves construction cost for developing country like Nepal (Mishra, 2019). The word 'shopping' having originated from the word 'shop' refers to the act of buying goods from shops. It involves a customer browsing the accessible goods offered by one or more retailers with the intention to purchase the best of 
products. It is also considered to be a leisure activity in addition to being an economic one, in some context. Such good might include household goods of daily use or fancy goods.

While there are still shops in market and people take to buying goods from them, there also has been a tremendous rise in services like Departmental Stores, Superstores and Marts. Unlike shops that present a customer with one kind of goods and fall under the category of hardware shops, gift shops, retails shops, electronic shops, furniture showrooms, clothes shops, kitchen ware etc. a departmental store, superstore or a mart present to their customer a variety of goods at a place in a way it is easier for a customer to meet all their needs. Today, when life has been too office-bound and ambitious, it has been imperative that one dedicates as little time as possible for household chorus. This has given rise to people's willingness to prefer such stores to individual shops. This is one reason twenty-first century has witnessed a tremendous rise in customers' willingness and thus in the establishment of such stores.

It has been observed that departmental stores are no longer the only stores providing such services to the public and own no autonomy in the market like some decades ago. There have been Superstores and Shopping Malls and Marts. In Nepal's context itself, rise of such services have seen a major upliftment in the past decade. Bhatbhateni, established in a number of place has emerged as a dominant place in the case of shopping in Nepal.

However smaller chains such as Big Mart have also managed to carve its own place in the changing shopping environment of Kathmandu and has become one of the most desired service provider these days. Big mart was established in July 2009. Over a span of few years, it has emerged as one of the growing retail stores in Nepal especially in Kathmandu. Currently there are 18 stores located all over Kathmandu. Despite fierce competition from other more established stores such as Bhatbhateni, Saleways and the like which has comparative advantage in terms of scale and history, Big mart continues to grow.

Big Mart is operated by Mega mart pvt. Ltd with its main warehouses located at Balkhu and Kalopul from where all items except for perishable goods such as vegetables and fruits are supplied. While the major target groups are foreigners and expats, it tries to fulfill the demand of people from every economic status. Its main strategy has been to remove the middle men from the transaction and to source products directly from the farmers so it can benefit both farmers as well as customers. It provides loyalty program to customers which rewards customer's loyalty with monthly vouchers. In 2012 it had around 45000 loyal customer cardholders. It has also developed a mobile app for easy communication with their customers. It allows customers to browse products, location of nearest store, track their shopping history, online order and purchase etc. Such technological advancement has also played a role in keeping up with the current market.

Not a lot of literature can be found on the location selection process for retail stores in Kathmandu although it is evident that some strategies must have been used.

\section{Need of Research}

The main aim for this research it to understand how retail chains like Big Mart choose their location in order to maintain its existence in a competitive environment as well as maximize its profit. It is 
well known that the selection of location is vital for successful operation of stores. Especially in case of retail stores the location has huge importance. Researches have been done regarding the location analysis of retail stores in global context (Fahui Wang, 2014). Since such researches have shown that various criteria that are used for location selection differ from one place to another, it can be implied that a single model cannot explain all cases because of unique setting of places. So, it is very necessary to understand the context such as economic, demographic, cultural, geographical etc. aspects that occupies the background in the location process along with business and marketing strategies. This research focuses on such factors which influenced the location selection for Big Mart in Nepal.

\section{Importance of Research}

A knowhow of the approach towards selection of location can help policy makers in making land use plan for commercial purpose to attract investors. It may also aid similar commercial enterprises during location selection process.

\section{Research Question}

How do different factors in combination affect the selection of location by retail chain (Big Mart) and what is the predominant factor?

\section{Scope and Limitation}

The results are overwhelming based on observation as there was no other source of reliable data. Because of the concerned authorities not entertaining any type of questions, the results are highly subjective. Since the results are based on observations of supply chain of Big Mart, it might not be sufficient enough to explain the location selection criteria for other chain outlets.

\section{Literature Review}

As a well-known real estate mantra is "location, location, location" and this seems to hold particularly true for retail chains as it is cited as one of the most important variable factors affecting "the profitability and sales performance of the management" (Erbiyik, Ozcan, \& Karaboga, 2012, p. 1). Although there may be other factors that affect the success or failure of retail stores, the adverse effects of a poor location choice are formidable and non-removable.

The selection of a new location for an existing store is a strategic decision requiring a long-term investment. Since new location is an additional cost there is significant financial burden on chains looking at expansion as well as the danger of their image getting damaged if the right decision in store location selection is not implemented (Turhan, 2013).

Retail Chain or Chain Stores are retail channels that share a brand and central management, and typically have uniform business approaches and practices. Chain businesses have come to direct the market in several parts of the world. For retail chain, location is highly influencing factor in terms of profit maximization. Due to the nature of the transactions carried out in various types and 
sizes of stores, they are likely to be found in regional centers (urban cores) or in close proximity to such centers. (Önera \& Larssona, 2005)

Retailers are internally and externally driven to open new stores. Externally, they are faced with significant pressures from competitors to expand their network of stores. Internally, shareholders expect tangible evidence of expansion and growth (Breheny, 1988 c.f. Ladle, Stiller, \& Stiller, 2009). Intrinsically, retailers seek to increase sales and market share, to better service their customer base, to hedge against the uncertainties of the market environment, and to obtain economies of scale in advertising and distribution (McLafferty \& Ghosh, 1987 c.f. Ladle, Stiller, \& Stiller, 2009).

\section{Parameters of Location Selection}

There have been various studies that have studied the various parameters used for location selection. The four main selection criteria that have been cited in many researches are as followspopulation, retail settlement, costs and competition. (Akalina, Turhan, \& Sahin, 2013)

In terms of population, the amount of money that people are willing to spend for buying retailers' goods, population growth rate and coherent target market in terms of demographics such as gender, education, age, occupation etc are studied. Retailers desire to reach people who are willing to spend money for buying goods. Since the rate of retail expenditures per capita are expected to increase by a rise in population density, the population growth is a good indicator. In addition the coherent target market is a key to eventual success of any one location as its target market is hugely defined by where it is established.

In terms of retail settlement the location selection decision are based on ease in accessibility, parking facilities and location at street corner or road intersection. Ease in accessibility not only refers to people's ability not only to find the store quickly and easily but also get inside and out of it. People value quick and easy excursion time and since some may come by automobile adequate parking facilities is a must. A good visibility from the road for example being located at a road intersection is preferred.

In terms of costs, building and/or renovating buying or renting and transportation and or warehousing costs of the physical store are involved.

In terms of competition the competitors' store numbers, the spatial proximity to competitors travel time and closeness to other public amenities is examined. Since customers are not bound to only one store they can visit several other stores. Therefore, the number of stores in a market where to be entered is very important for retailers in attempting to entice the consumer to buy more their goods. Purchase incidence varies by depending upon the spatial proximity to competitors. The probability of patronizing a certain shopping area is inversely related to its distance from the consumer (i.e. travel time). As such, all retailers should consider the presence of magnet stores (i.e. culture, amusement and relaxation centers) as an advantage since the stores attract more trade from greater distances.

Other researcher have been also studied and has been summarized as below: 
Table 1: Researches and their criteria

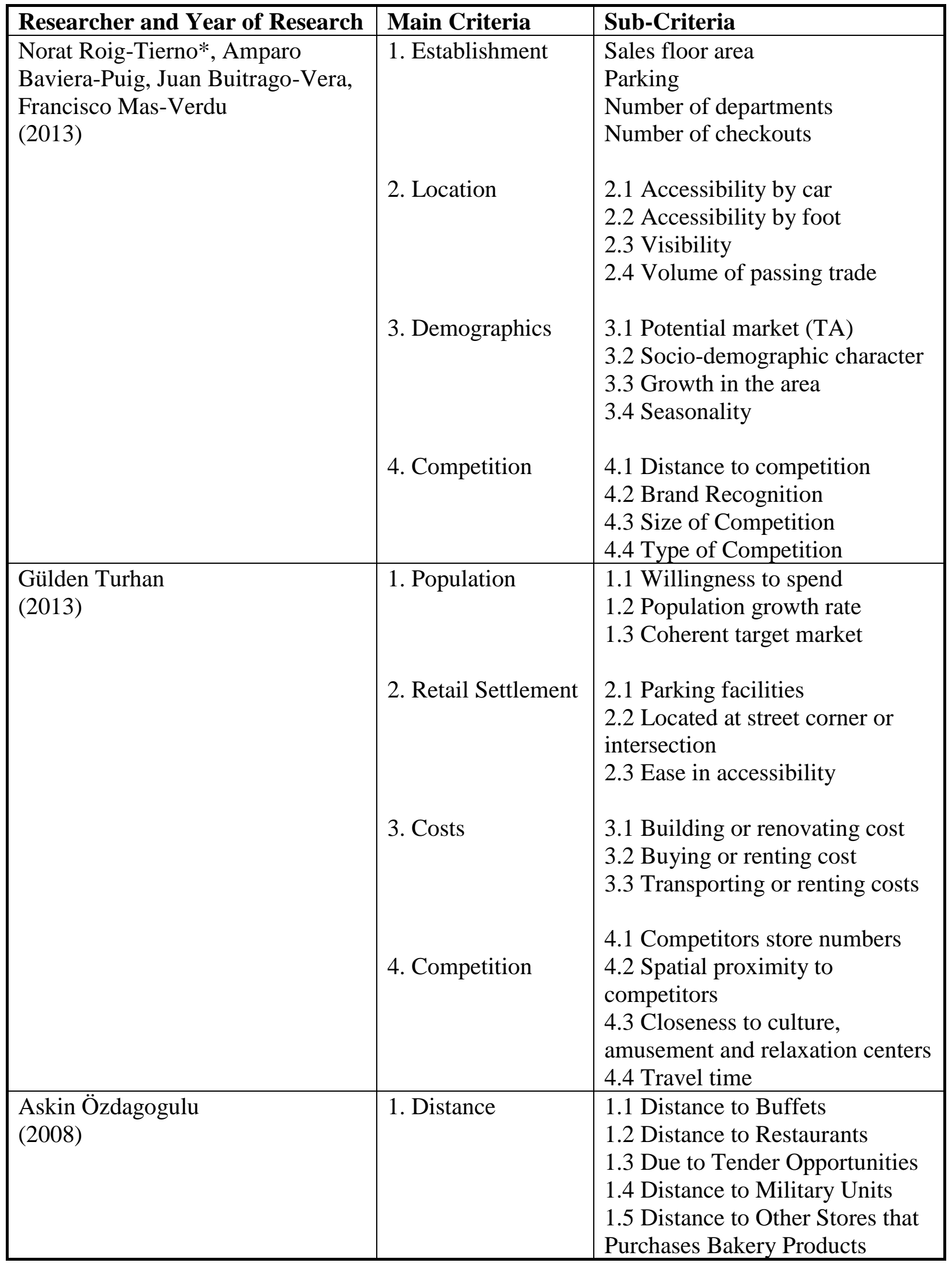




\begin{tabular}{|c|c|c|}
\hline & $\begin{array}{l}\text { 2. Traffic Jam } \\
\text { 3. Features } \\
\text { 4. Demand } \\
\text { Potential } \\
\text { 5. Close } \\
\text { Environment }\end{array}$ & $\begin{array}{l}\text { 2.1 Parking Place Facilities } \\
\text { 2.2 Vehicles Traffic Density } \\
\text { 2.3 Existence of Alternative } \\
\text { Roads } \\
\text { 3.1 Square Area (m2) } \\
\text { 3.2 Formation } \\
\text { 3.3 Distance to Main Road } \\
\text { 3.4 Price } \\
\text { 4.1 High Level Demand } \\
\text { 4.2 Medium Level Demand } \\
\text { 4.3 Low Level Demand } \\
\text { 5.1 Existence of Competitors } \\
\text { 5.2 Ease of Maintenance and } \\
\text { Repair } \\
\text { 5.3 Energy Provisions }\end{array}$ \\
\hline $\begin{array}{l}\text { Yang C.L., Chuang S.P., } \\
\text { Huang R.H. and Tai } \\
\text { C.C. } \\
\text { (2008) }\end{array}$ & $\begin{array}{l}\text { 1. Market } \\
\text { Attraction } \\
\text { 2. Customer } \\
\text { Features } \\
\text { 3. Features for } \\
\text { location } \\
\text { 4. Competition }\end{array}$ & $\begin{array}{l}\text { 1.1 Market Size } \\
\text { 1.2 Passenger Traffic } \\
\text { 1.3 Competition } \\
\text { 1.4 Safety } \\
\text { 2.1 Number of customers } \\
\text { 2.2 Density of customers } \\
\text { 2.3 Income Level } \\
\text { 2.4 Purchasing Power } \\
\text { 2.5 Brand Loyalty } \\
\text { 2.6 Rentals } \\
\text { 2.7 Elasticity of Rental Contract } \\
\text { Period } \\
\text { 2.8 Store Size } \\
\text { 3.1 Personnel Recruitment } \\
\text { 3.2 Expected Income } \\
\text { 3.3 Visibility of store } \\
\text { 4.1 Competitors store numbers } \\
\text { 4.2 Spatial proximity to } \\
\text { competitors } \\
\text { 4.3 Closeness to culture, } \\
\text { amusement and relaxation centers } \\
\text { 4.4 Travel time }\end{array}$ \\
\hline
\end{tabular}




\section{Methodology}

For this research the Analytical Hierarchy Process (AHP) has been used. This method is used for solving multi-criteria decision problems and can effectively handle both qualitative and quantitative data. The primary purpose of the research is to understand the most suitable retail location selection for Big Mart by analysis of the various criteria and attributes involved which has been made easy by the AHP method.

It is necessary to compare various factors in the location selection problem. It has been possible to make comparisons and calculations of predetermined criteria. Different criteria and its attributes are arranged in a hierarchal structure. Thus designed hierarchal structures are compared with each other in sequential order. All factors are divided into four major criteria with the help of literature study i.e. Demography, Competition, Economic factors and Features. Further these criteria are divided into three sub - criteria. These four major criteria is compared with each other to obtain a weighted values for each. Similar method is followed for sub-criteria. Relevant comparisons and results that have been obtained with the help of literature review have been prepared. Comparison matrixes for main criteria and relevant weights (degree of importance) have been allotted.

Each criterion and attribute have been compared with others in a pair wise fashion to allot weights. These weights from 1 to 9 represent perceived importance of each criterion and attribute.

Table 2: weightage \& explanation

\begin{tabular}{|l|l|l|}
\hline Intensity & Definition & Explanation \\
\hline 1 & Equally important & Two factors contribute equally to the objective \\
\hline 3 & $\begin{array}{l}\text { Somewhat more } \\
\text { important }\end{array}$ & Experience and judgement slightly favour one over the other \\
& $\begin{array}{l}\text { Much more } \\
\text { important }\end{array}$ & $\begin{array}{l}\text { Experience and judgement strongly favour one over the } \\
\text { other }\end{array}$ \\
\hline 5 & $\begin{array}{l}\text { Very much } \\
\text { important }\end{array}$ & $\begin{array}{l}\text { Experience and judgement strongly favour one over the } \\
\text { other. Its importance is demonstrated in practice }\end{array}$ \\
\hline 9 & $\begin{array}{l}\text { Absolutely more } \\
\text { important }\end{array}$ & $\begin{array}{l}\text { The evidence favouring one over the other is of the highest } \\
\text { possible validity }\end{array}$ \\
\hline $2,4,6,8$ & Intermediate values & When compromise is needed \\
\hline
\end{tabular}

In this research demography has been identified one of the four major criteria. Demographic factors cover the attributes like (i) income of people, (ii) growth rate of population in particular area. It also deals with the type of (iii) target population in that region.

Competition, in the other hand, deals with (i) geographical and commuting distance of store and consumer, (ii) size and type of competition in that particular location along with (iii) brand recognition.

Economic factors deals with all activities which are related with cost. The (i) value of land or its renting cost is of major issue. (ii) Costs related with building required structures or renovating existing one are covered in this section. It also focuses on (iii) transportation cost which is usually cost of transpiration from warehouse/ source to stores. 
Other features deal with factors like (i) accessibility, (ii) visibility and (iii) traffic issues. Accessibility refers to the provision of necessary roads access to the store whereas visibility refers to capability of being readily noticed. Traffic is vehicles moving along a certain route as well as the volume of customers visiting a business establishment.

Criteria and attributes

1) Demography

- Income of people

- $\quad$ Growth Rate of people

- Target Population

2) Competition

- Distance (Physical and communication)

- Brand recognition

- Size and type of competition

3) Economic Factors

- Building and renovating cost

- Buying or renting cost

- Transportation

4) Features

- Accessibility \& visibility

- Traffic

- Services (Electricity, Communication)

\section{Analysis and Finding}

As discussed in the previous section of this paper the comparison and calculations have been done using AHP by forming hierarchy for main criteria and attributes in sequential order.

The first comparison matrix has been done between the four main criteria; demography, competition, economic factors and features.

\subsection{Demography Vs Competition}

Demographic factors are weighted significantly higher than competition with the help of literature and contextual studies. From the contextual studies and observation it has been found that the selected Big Mart outlet is located in the area where there are high income group and foreigners and expats residing currently. It has been suggested that they possess higher purchasing power in comparison to an average Nepali. Such scenario corresponds with Big Mart's business model as referred by newspaper articles. "We are expecting foreigners and expats to be the major customers" (Giri, 2012)

There are total six outlets of Big Mart in Lalitpur. Among them four are situated inside ring road within approxiamately $2 \mathrm{~km}$ distance while Bhaisepati and Khumaltar outlets are outside ring road. There are also smaller convenience stores around Bakhundol area where our case site is located in addition to larger counterparts such as Bhatbhateni Supermarket (located at Krishnagalli), Saleways (located at Jawalakhel) and Namaste Supermarket (located at Pulchowk) It can be seen through the emergence pattern of Big Mart; the opening of an outlet within a close distance from 
another of its own outlet and several other competing outlets, that there is a significant population that is willing to consume offerings from Big Mart alone.

\subsection{Demography Vs Economic Factors}

Demographic factors are weighted as moderately higher in this context. In most of the cases it is evident that land is usually rented for store operation. It could be seen in case of World Trade Center, Tripureshwor.

From literature it is inferred that the presence of a strong consumer base is the most important factor for retailers to establish their outlet. Big Mart has opened an outlet. The transportation cost from the two main warehouse in Balkhu and Kalopul does not seem to be a deciding factor in location selection in our case as it can be seen that outlets of Big Mart has been located as far as Bhaktapur.

\subsection{Demography vs Feature}

Demographic factors are weighted as significantly higher in this context. Since all of the Big Mart outlets are located inside Kathmandu valley where there is good provision of infrastructure and communication, site features may not have been an instigator to location selection in case of Big Mart as compared to demographic factors. In our case site, visibility and traffic flow does not seem to rank high in the priority list as the outlet is located away from the main road. On the other hand parking seems to be prioritized in our case site as the assumption is that the higher income groups who are the main target will come by car to shop.

\subsection{Competition vs Economic Factor}

Economic factors weighted slightly higher than competition. Despite the presence of bigger chain like Bhatbhateni and Saleways, Big Mart has not been discouraged to open its outlet in their proximity. Big Mart seems to economize in terms of building and rental cost as it can be seen that it operates at a single floor usually on the ground floor of an already established building and chooses to expand by adding new outlets on a new location rather than going vertical. In our case site it can also be seen that the mart functions on a single ground floor.

\subsection{Competition vs Features}

Competition is weighted moderately higher than features. It seems that Big Mart would rather establish its outlet at a site with inferior features for example lack of visibility in our case area rather than risk losing its niche market to other competitors. It could also be one of the reasons why Big Mart opens a number of outlets to give tough competition to the existing ones rather than establish a single one in a superior site.

\subsection{Economic Factors Vs Features}

Similarly, Economic factor is weighted moderately higher than features. 
As discussed in the previous section of this paper the comparison and calculations have been done using AHP by forming hierarchy for main criteria and attributes in sequential order.

The first comparison matrix has been done between the four main criteria; demography, competition, economic factors and features.

Table 3: Comparison of Main Criteria

\begin{tabular}{|c|c|c|c|c|c|}
\hline \multicolumn{6}{|c|}{ Chain Retail Location Selection Main Criteria Comparison Matrix } \\
\hline Main Criteria & Demography & Competition & Economic Factors & Features & Degree Of Importance \\
\hline Demography & 1 & 5 & 3 & 7 & 54.77 \\
\hline Competition & & 1 & $1 / 3$ & 5 & 14.48 \\
\hline Economic Factors & & & 1 & 5 & 25.58 \\
\hline Features & & & & 1 & 5.17 \\
\hline & & & & $\mathrm{CR}$ & 0.094469951 \\
\hline
\end{tabular}

From the analysis of above table, Demographic factors are most significant criteria for location selection by retail chain store (Big Mart). It is concluded that it is in sequential order as; $54 \%$ Demography, 25\% Economic factors, 14\% Competition and 5\% Features. (Since the incompatibility ratio in comparison matrixes is generally $<10 \%$, the incompatibility ratio in this study could be found in acceptable level i.e. $0.094<0.10$ ).

After comparing the main criteria among themselves, each sub-criteria group ( 2 nd level) has been compared in their own groups. Three sub-criteria 'Income of people', 'Growth rate of people' and 'Target population' of main criteria 'Demography' are compared and the degree of importance are calculated which are as follows;

Table 4: Comparison of sub-criteria

\begin{tabular}{|l|l|l|l|l|l|}
\hline \multicolumn{5}{|c|}{ Comparison matrix for sub criteria for "Demography" main criteria } \\
\hline & $\begin{array}{c}\text { Income of } \\
\text { people }\end{array}$ & $\begin{array}{c}\text { Growth } \\
\text { Rate }\end{array}$ & $\begin{array}{c}\text { Target } \\
\text { Population }\end{array}$ & $\begin{array}{c}\text { Degree of } \\
\text { Importance }\end{array}$ & \multicolumn{1}{|c|}{ Overall } \\
\hline $\begin{array}{l}\text { Income of } \\
\text { people }\end{array}$ & 1 & 7 & 0.2 & 25.95 & 14.21 \\
\hline Growth Rate & & 1 & $1 / 7$ & 6.54 & 3.58 \\
\hline $\begin{array}{l}\text { Target } \\
\text { Population }\end{array}$ & & & 1 & 67.51 & 36.97 \\
\hline & & & & CR & 0.092326321 \\
\hline
\end{tabular}

From analysis of comparison matrix for sub criteria for 'Demography', the most important sub criteria is 'Target Population' with $67.51 \%$, and other sub criteria in sequential order are; 'Income of people' $25.95 \%$ and 'Growth Rate' with $6.54 \%$. (Since the incompatibility ratio in comparison matrixes is generally $<10 \%$, the incompatibility ratio in this study could be found in acceptable level i.e. $0.092<0.10)$.

Similarly, following tables have been obtained as the results of analysis for degree of importance for sub criteria for 'Competition' main criteria; 
Table 5: Comparison of Sub-Criteria

\begin{tabular}{|l|l|l|l|l|l|}
\hline \multicolumn{5}{|c|}{ Comparison matrix for sub criteria for "Competition" main criteria } \\
& Distance & $\begin{array}{c}\text { Brand } \\
\text { Recognition }\end{array}$ & $\begin{array}{c}\text { Size \& Type of } \\
\text { competition }\end{array}$ & $\begin{array}{c}\text { Degree of } \\
\text { Importance }\end{array}$ & Overall \\
\hline Distance & 1 & 5 & 5 & 67.14 & 9.72 \\
\hline Brand Recognition & & 1 & $1 / 4$ & 9.43 & 1.37 \\
\hline $\begin{array}{l}\text { Size \& Type of } \\
\text { competition }\end{array}$ & & & 1 & 23.43 & 3.39 \\
\hline & & & & CR & 0.074815271 \\
\hline
\end{tabular}

From analysis of comparison matrix for sub criteria for 'Competition', the most important sub criteria is 'Distance' with $67.14 \%$, and other sub criteria in sequential order are; 'Size \& Type of Competition' $23.43 \%$ and 'Brand Recognition' with 9.43\%. (Since the incompatibility ratio in comparison matrixes is generally $<10 \%$, the incompatibility ratio in this study could be found in acceptable level i.e. $0.075<0.10$ ).

Similarly, following tables have been obtained as the results of analysis for degree of importance for sub criteria for 'Competition' main criteria;

Table 6: Comparison of Sub Criteria

\begin{tabular}{|l|l|l|l|l|l|}
\hline \multicolumn{5}{|c|}{ Comparison Matrix for Sub Criteria for "Economic Factors" main criteria } \\
\hline & $\begin{array}{c}\text { Building \& } \\
\text { Renovating }\end{array}$ & $\begin{array}{c}\text { Buying \& } \\
\text { Renting }\end{array}$ & $\begin{array}{c}\text { Transporta } \\
\text { tion }\end{array}$ & $\begin{array}{c}\text { Degree of } \\
\text { Importance }\end{array}$ & \multicolumn{1}{c|}{ Overall } \\
\hline $\begin{array}{l}\text { Building \& } \\
\text { Renovating }\end{array}$ & 1 & $1 / 5$ & 6 & 24.66 & 6.31 \\
\hline $\begin{array}{l}\text { Buying \& } \\
\text { Renting }\end{array}$ & & 1 & 7 & 68.52 & 17.53 \\
\hline Transportation & & & 1 & 6.83 & 1.75 \\
\hline & & & & CR & 0.085435963 \\
\hline
\end{tabular}

From analysis of above comparison matrix for sub criteria for 'Economic Factors', the most important sub criteria is 'Buying \& Renting' with $68.52 \%$, and other sub criteria in sequential order are; 'Building \& Renovating' 24.66\% and 'Transportation' with $6.83 \%$. (Since the incompatibility ratio in comparison matrixes is generally $<10 \%$, the incompatibility ratio in this study could be found in acceptable level i.e. $0.085<0.10$ ).

Similarly, following tables have been obtained as the results of analysis for degree of importance for sub criteria for 'Features' main criteria;

Table 7: Comparison of Sub-Criteria

\begin{tabular}{|l|l|l|l|l|l|}
\hline \multicolumn{6}{|c|}{ Comparison Matrix for Sub Criteria for "Features" main criteria } \\
\hline & $\begin{array}{c}\text { Accessibility } \\
\text { \& Visibility }\end{array}$ & Traffic & $\begin{array}{c}\text { Legal issues, } \\
\text { services }\end{array}$ & $\begin{array}{c}\text { Degree of } \\
\text { Importance }\end{array}$ & Overall \\
\hline Accessibility \& Visibility & 1 & $1 / 3$ & $1 / 5$ & 10.62 & 0.55 \\
\hline Traffic & & 1 & $1 / 3$ & 26.05 & 1.35 \\
\hline
\end{tabular}




\begin{tabular}{|l|l|l|l|l|l|} 
Legal issues, services & & 1 & 63.33 & 3.27 \\
\hline & & & & CR & 0.047725 \\
\hline
\end{tabular}

From analysis of above comparison matrix for sub criteria for 'Features', the most important sub criteria is 'Legal issues \& Services' with $63.33 \%$, and other sub criteria in sequential order are; 'Traffic' $26.05 \%$ and 'Accessibility \& Visibility' with $6.83 \%$. (Since the incompatibility ratio in comparison matrixes is generally $<10 \%$, the incompatibility ratio in this study could be found in acceptable level i.e. $0.048<0.10$ ).

\section{Results}

(Location selection - one of the most important decision in marketing strategy (highly critical decision)

Distribution channel are vital for successful marketing of product and overall business growth Need to define priority criteria based upon retail's own characteristics, goals \& objectives AHPdone in group, from experiences and knowledge

This is a study which studies selection of location by chain retail stores with reference to Big Mart in Bakhundol. The aim of this study is to understand how such chain stores select most convenient location in our context. To understand such multi criteria problem we used AHP method which considers both qualitative and quantitative approach in decision making. Usually experts and marketing managers utilizes their experiences and knowledge regarding qualitative analysis with the help from literatures. But in our study it is based upon literature and contextual studies as well as case observation. As the result of this study, a research model structure of comprising 4 main criteria and 12 sub-criteria has been obtained.

\section{Acknowledgements}

We would like to express our gratitude to Dr. Kirti Kusum Joshi for providing us an opportunity to conduct this research and also for his continuous guidance in completion of this research project.

We are also grateful to Mrs. Deepa Shakya for her guidance and support during this project. Also, we would like to express our heartily thanks to Department of Architecture \& Urban Planning for co-ordination and continuous support throughout the study.

Finally, we are also indebted to Big Mart, Bakhundol for their cooperation and their valuable time during the survey.

\section{References}

[1] Akalina, M., Turhan, G., \& Sahin, A. (2013). The Application of AHP Approach for Evaluating Location Selection Elements for Retail Store: A Case of Clothing Store. International Journal of Research in Business and Social Science, 5-20.

[2] Erbiyik, H., Ozcan, S., \& Karaboga, K. (2012). Retail store location selection problem with multiple analytical hierarchy process of decision making an application in Turkey. Procedia - Social and Behavioral Sciences , 1-10. 
[3] Fahui Wang, C. C. (2014). Location analysis of retail stores in Changchun, China: A street centrality.

[4] Friedman, M. (1955). The Role of government in Education.

[5] Ladle, J. K., Stiller, D., \& Stiller, D. (2009). Retail Site Selection:A New and Innovative Model for retail development. Cornell Real Estate Review, 1-29.

[6] Mishra.A.K., Mallik.K. Factors and Impact of Risk Management Practice on success of Construction Projects of Housing Developers, Kathmandu, Nepal. International Journal of Sciences: Basic and Applied Research (IJSBAR) (2017) Volume 36, No 7, pp 206-232

[7] Önera, Ö., \& Larssona, J. P. (2005). Location and Co-location in Retail.

[8] Mishra AK, Chaudhary U. Cost Effectiveness Assessment of Different Nepalese Cement Brands for Selected Sites of Supermarket.J Adv Res Const Urban Arch 2018; 3(3): 12-33

[9] Mishra.A.K. Implementation Status of Value Management in Project Management Practice in Nepal. International Journal of Management Studies. Vol.-VI, Issue -1(1),January201

[10] Turhan, G. (2013). The Application of AHP Approach for Evaluating Location Selection Elements for Retail Store: A Case of Clothing Store. International Journal of Research in Business and Social Science, 5-20.

\footnotetext{
*Corresponding author.

E-mail address: mansikarna2015@ gmail.com
} 